\title{
ECO - FRIENDLY NATURAL COLORS YIELDING FLOWERING PLANTS OF COLLEGE CAMPUS KILA BHAVAN INDORE DISTRICT (M.P.) - A SURVEY REPORT
}

\author{
Saroj Mahajan*, Padma Upadhya*, Malini Johanson**, Neelu Malviya*** \\ Department of Botany*, Department of Botany**, Department of Chemistry** \\ *Govt. Maharani Laxmi Bai Post Graduate College Kila Bhavan, Indore, MP, INDIA. \\ Govt. Bherulal Patidar P.G. College Mhow, MP, INDIA.
}

\section{INTRODUCTION}

Color is one of the elements of nature that made the human living more aesthetic and fascinating in the world. They are supposed to be associated with emotions, human qualities, seasons, festivals and passion in our life .I $n$ India, there are more than 450 plants that can yield bright colors. Natural dyes are environment friendly such, turmeric, the brightest ofnaturally occurring yellow color is a powerful antiseptic which revitalizes the skin, (R.Siva,2007)PunicagranatumL. (Anar)LawsoniainermisL.(henna), and manyother common natural color yielding plants(Hussein, 1997)The present study mainly focuses on some important plants having color yielding potential. As many as 25 species were screened for coloiouring. These species belonging to 25 genera and 18 families are presented in this paper. The botanical names, family,vernacular name and parts from which color is obtained and the colours fixed after treating withrecommended mordents. Natural colorants derived from flora and fauna are believed to be safe because of its nontoxic, non-carcinogenic and biodegradable in nature (Cristea\&Vilarem, 2003). Different parts of the plants were used for the extraction of dyes such asbark, leaves, flowers, etc and different types of mordents were used for fixing the dye into the fabric.Study of available literature shows that several studies werecarried out on natural color yielding plants in the recent past. (A. Rashmiel.al., 2004, Debajitand Tiwari 2005, Gour 2008 and Garget al., 2010) color yielding plants are not properly studied with reference to Madhya Pradesh, (Tiwariand Bharat 2008), (Choudhary and Upadhyay 2011) Present work is undertaken to study the color yielding plants of Sehore district.

\section{STUDY AREA}

College is basically a Fort of Holker Emperor .The area of Fort is 52610 Sq. Meter. Holker Emperor constructed it in 1860; it was constructed by cementand lime. The college established in 1963 in the Fort.The study site and surrounding area is rich in flora.Floristic composition is the major morphological characters of the plant community. Thus, a detailedsurvey of the floristic vegetation was carried out in and around the study site.After survey 25 plants selected for extraction of natural colors .

\section{MATERIAL AND METHODS}

Test of natural colors in Plant parts.

1.Squeeze the plant part preferably flowers and leaves between the fingers if color is dis charged, it may be a good source of natural color. 


\section{INTERNATIONAL JOURNAL Of RESEARCH -GRANTHAALAYAH

2.If the color is retained on the fingers even after washing the and with water, it may be a good source of natural dye with probably good wash fastness.

3. Crush the plant part in pestlemortar and smear the crushed plant paste on filter paper, if the color retains on paper, it may be a good source of natural dye.

4.Place this filter paper under table lamp for 3-hours, see if the color remains the same orfades off, if the color does not fade, it may be a good source of natural dye with good light fastness properties.

5.Shake boiled water and put crushed plant part, if it releases color into the water, it may be a source of natural color.

By following above procedure in laboratory recorded the different colors obtained from different plant parts which are present in college campus. Observation recorded and as shown in Table

\begin{tabular}{|c|c|c|c|c|c|}
\hline S.N. & Botanical name & Local name & Family & Plant part & Natural color \\
\hline 1 & Abutilon indicum Linn. & Kanghi, & Malvaceae & Flowers & Yellow \\
\hline 2 & Acacia nilotica Linn. & Babool & Mimosaceae. & Bark & Brown \\
\hline 3 & Aegle marmelosn linn. & Bel & Rutaceae & \multicolumn{2}{|c|}{ Fruit and barl Brown } \\
\hline 4 & Anthocephalus cadamba Miq. & Kadam. & Rubiaceae. & Bark & Brown \\
\hline 5 & Azadirachta indica.A. Juss. & Neem & Meliaceae & Bark & Brown \\
\hline 6 & Bouganvilia spectabilis & Kagaz ke phool & Nyctaginaceae & Flower & Red \\
\hline 7 & Bauhinia variegata Linn. & Kachnnar & Caesalpiniacea & Flower & Yellowish brown \\
\hline 8 & Carica papya & papita & caricaceae & leaf, fruits. & green, orange \\
\hline 9 & Catharanthus roseus Linn. & Sadabahar & Apocynaceae. & Flower & Cream yellow \\
\hline 10 & Clitoria ternatea Linn. & Aparajita & Fabeaceae & Flower & Blue \\
\hline 11 & Cassia fistula & amaltas & Caesalpiniacea & Flower & yellow \\
\hline 12 & Thevetia peruviana pers. & kener & Apocynaceae & flower & yellow \\
\hline 13 & Delonix regia Rafin. & Gulmoher & Caesalpiniacea & Flower & Red \\
\hline 14 & Hibuscus rosa-sinensis Linn. & jasum & Malvaceae & Flower & Violet \\
\hline 15 & Ixora coccinea Linn. & Rukmani & Rubiaceae & Flowers & Red \\
\hline 16 & Lawsonia inermis Linn. & Mehndi & Lythyraceae & leaf & orange \\
\hline 17 & Mangifera indica Linn. & Mango & Anacardiaceae & Bark & Brown \\
\hline 18 & Michelia champca Linn. & Champa & Magnoliaceae & Flower & yellow \\
\hline 19 & Nyctanthus arbortristis $L$. & Parijat & Oleaceae & Flower & Light brown \\
\hline 20 & Eucalyptus globules Labill & Neelgire & Myrtaceae & Bark & Khaki \\
\hline 21 & Psidium guajava Linn. & Amarud & Myrtaceae. & Bark & Brown \\
\hline 22 & Dalbergia sissoo Roxb. & seesham & Fabeaceae & Fruit, bark & Brown \\
\hline 23 & Mirabilis Jalapa Linn. & Gulabas & Nyctaginaceae & flower & Red \\
\hline 24 & Punica granatum Linn. & Anar & Punicaceae & fruit & brown \\
\hline 25 & Nerium oleander Linn. & Kenar & Apocynaceae & flower & pink \\
\hline & & & & & \\
\hline & & & & & \\
\hline & & & & & \\
\hline & & & & & \\
\hline & & & & & \\
\hline & & & & & \\
\hline & & & & & \\
\hline
\end{tabular}




\section{INTERNATIONAL JOURNAL Of RESEARCH -GRANTHAALAYAH

Art

\section{RESULT AND DISCUSSION}

From the observation and results, it can be oncluded that during Preliminary survey it was recorded that the college campus rich in vegetation luxuriant growth of trees, under shrub, shrubs and herbs were registered . Diwangi (1980) studied the vegetation of Indore district. From the study area 25 plants recorded as a natural color yielding plants. The plant part flowers and bark dominated as a plant parts from which the brown and yellow natural color obtained.Nowadays most of the natural colors are interested to use natural dye materials in the same ways used for synthetic dyes. Textile dyers must know the chemistry of these natural colors and its Use of suitable binary or ternary mixtures of similar or compatible natural dyes for coloring natural ecofriendly textiles in variety of soothing /uncommon shades with eco-friendly mordants and finishing agents are the most desirable product of the customers for future. Thus with the worldwide concern over the use of eco-friendly and biodegradable materials, the use of natural dyes has undoubtedly once again gained interest and momentum.

\section{REFERENCES}

1 R. Siva, Status of natural dyes and dyeyielding plants in India, Current science, vol.92, April 2007, no. 7, 10.

2 Hussein, S. A. M., Barakat, H. H., Merfort, I.andNawwar, M. A. M., Tannins from theleaves of Punicagranatum. Photochemistry,45,1997, 819-823.

3 Cristea G. Y., and Vilarem S. J (2003) : Ultrasound assisted enhancement in natural dye extraction frombeetroot for industrial applications and natural dyeing of leather, Ultrason. Sonochem., 16 (6) : 782-789.

4 Rashmi A, GeentaMahale, RK Sunanda and M Javed: Effect of katha leaves dye onUSA sheep breed wool. NPR. 2004; 3(6): 413 -417.

5 Debajit M, Tiwari SC: Natural dyeyielding plants and indigenous knowledge on dye preparation in Arunachal Pradesh, Northeast India. Curr. Sci., 2005; 88(9):14741480.

6 Gour D: Tradition dye yielding plants of Uttarakhand, India. Natural Product radiance. 2008; 7(2): 154

7 Tiwari SC and Bharat Ajay: Natural dyeyielding plants and indigenous knowledge of dye preparation in Achanakmar -Amarkantak Biosphere Reserve, Central India. NPR, 2008; 7(1): $82-87$.

8 Choudhary MS and Upadhyay R: Observation on natural dye yielding plants of Central Narmada Valley India. Jun. of plant development Sciences. 2011; 3 